\title{
Study on Specialized Curriculum Setting of College Preschool Education
}

\author{
Xia $\mathrm{Li}^{1}$, Ruohong $\mathrm{Li}^{2}$ \\ ${ }^{1}$ Preschool education college, Longnan Teachers' College, Longnan Gansu, 742500, China \\ ${ }^{2}$ Dangchang Vocational School, Longnan Gansu, 748500, China
}

Keywords: College, Pre-school education, Specialized curriculum setting, Study.

\begin{abstract}
This paper proceeds with the need of kindergartens and other preschool education institutions as well as the work conditions of kindergarten teachers, uses the normal university as the research case to comprehensively know the specialized curriculum setting of preschool education, then further analyzes the current situation of specialized curriculum setting of college preschool education in our country and puts forward some suggestions on how to perfect China's specialized curriculum setting of preschool education in colleges.
\end{abstract}

\section{Introduction}

Preschool education, which is the beginning phase of one's learning life, plays a decisive role in one's future development. With the continuous development of society, people gradually realized the significance of preschool education, so preschool education has attracted widespread attention of all sectors of society. Besides, the society's increasing needs for preschool education also has a high requirement for preschool education. This paper selects a normal university as a case mainly because undergraduate kindergarten teachers are the leading front workers of preschool education and they have more profound experience and understanding of the shortcomings in specialized curriculum setting of preschool education.

\section{Specialized curriculum content of preschool education in China's colleges}

At the present stage, the preschool curriculum in China's colleges mainly consists of the common courses, specialized basic courses, specialized courses and practice courses. The common courses refer to Marxism-Leninism theoretical knowledge, ideological and political course and other basic knowledge including English, computer and mandarin etc. As specialized theoretical knowledge which must be mastered by graduates majoring in preschool education, the specialized basic courses not only include pedagogy, psychology and other basic courses, but also include a variety of specialized basic skill courses for preschool education; specialized courses refer to the specialized theories and skills which must be mastered by graduates majoring in preschool education; practices courses refer to all sorts of probation and internship activities ${ }^{[1]}$.

The contents studied in this paper are the rest courses except for the common courses; besides, such specialized courses are divided into three types: knowledge, skills and practice. The knowledge courses cover all kinds of theoretical knowledge which must be grasped by students majoring in preschool education; skill courses consist of various skills which must be mastered by students majoring in preschool education; practice courses are dominated by graduates' educational probation.

\section{Analysis on specialized curriculum setting of preschool education in a normal university}

The specialized curriculum setting of preschool education is to arrange the teaching contents of an academic year according to a certain rule and form a scientific and reasonable educational system by selecting relevant course contents and clarifying the teaching contents and teaching hours of each discipline based on the training objective of preschool education major in colleges. 


\section{Major curriculum setting in undergraduate universities.}

The preschool education major in junior colleges mainly aims to cultivate applied talents, which meet the social development need, while the preschool education major in undergraduate universities pays more attention to cultivating professional talents which can get engaged in researches. With the continuous development of society, it also requires a growing number of kindergarten teachers. The majority of junior colleges had adjusted their talent cultivation objectives and gradually develops in the direction of cultivating senior applied professionals, largely narrowing the difference in cultivation of kindergarten teachers between junior colleges and undergraduate universities. Therefore, undergraduate universities need to improve cultivating spirit and quality of kindergarten teachers, strengthen communications with parents of infants and make other improvements so as to give full play to the advantages of students majoring in undergraduate preschool education.

As for the specialized curriculum setting of preschool education, undergraduate colleges strictly comply with the sequence of theoretical knowledge education first and then practical skill education and the sequence of basic knowledge and skill learning first and then professional knowledge and skill learning. Besides, universities pay attention to teaching practice. Many undergraduate universities began to adjust their preschool education curriculums to enhance students' teaching practice efficiency and quality. Furthermore, some universities may properly prolong students' internship period so that they can have sufficient time to learn their future job contents and working conditions. However, due to the complicated and wide range of curriculum contents of preschool education major, the occurrence of some unreasonable phenomena is unavoidable during practical arrangement. For instance, some teachers shorten the theoretical knowledge teaching time so that students fail to participate in enough skill training and guidance. Meanwhile, the continuously growing social need results in that the undergraduate universities' basic skill education fails to meet undergraduate students' learning needs for skills; therefore, they require universities to set more characteristic skill courses so that they can learn some professional skills and thus can have some advantages in future employment.

During the implementation of preschool education major curriculum, undergraduate universities should use advance teaching modes and enhance the teaching effect to guarantee the effectiveness of curriculum implementation. With the society's ceaselessly growing needs for professional preschool education talents, undergraduate universities continuously have been opened up preschool education majors and have carried out the enlarged enrollment policy so the number of students has been increasing rapidly and some difficulties have been caused for the smooth implementation of major curriculum ${ }^{[2]}$. The rapidly increasing number of students is a huge ordeal for both universities' hardware facilities and teachers' teaching ability. Students' education cannot be separated from teachers' guidance but a series of problems triggered by the increase in the number of students have caused many troubles for undergraduate teachers.

\section{Analysis on specialized curriculum setting of preschool education at the present stage.}

1) Analysis on the satisfaction degree of specialized courses

Students' dissatisfaction with the major courses mainly lies in the teaching mode, skill and practice courses. They think the specialized practice setting is rather weak in universities. Meanwhile, they are dissatisfied with the contents, structure and teachers' individual qualities of specialized courses to some extent.

Graduates, who have been working, are not satisfied with the professional skills and practice courses in the preschool major curriculum.

2) Reasons for students and graduates' dissatisfaction with curriculum setting

Firstly, because of the increased number of students due to universities' enlarged enrollment, it is required to add classes for preschool education major; this not only causes some difficulties in students' class period teaching arrangement but also brings a new challenge to universities' faculty. Besides, the increase in the number of students also has a high requirement for the quality and quantity of teachers, and meanwhile gives an ordeal for the hardware facilities in universities. 
Therefore, with the growing number of students, universities should take corresponding measures to guarantee that each student can have a chance for skill trainings with both the quality and quantity assured.

Secondly, the college resource utilization rate is very low. College resources can be divided into tangible and intangible resources based on the forms of their component elements. Intangible resources are the values shown during colleges' utilization or development of hardware resources, such as technologies and management. Tangle resources mean college resources which can be directly utilized or developed during education, such as the financial resources and material resources. In the condition of unchanged total quantity of college resources, the higher resource utilization rate will help the more rapid development of colleges. However, a college resource dilemma is resulted in due to many colleges' failure to scientifically and reasonably utilize their respective resources to enhance their resource utilization rates at the current stage. For instance, there are children observation rooms for many preschool education majors. However, some colleges use them as dance studios; besides, some of teaching aids even remain unopened. Such unused teaching aids will become finally damaged and even be discarded due to the long-term nonuse and the lack of custody by specially assigned personnel. In addition, if a kindergarten teacher has a professional skill, not only he/she can enlighten children in a better way but also this is a key point to help a teacher to remain invincible in the fierce employment competition. Thus, colleges should carry out characteristic specialized skill trainings based on their own conditions because this can not only improve students' comprehensive quality but also lay a good foundation for their future employment.

Finally, the increase in the number of college students also results in teachers' heavy teaching tasks, so some teachers of a weak sense of responsibility may have bad attitudes toward work and this may affect the smooth implementation of professional teaching of preschool education in colleges. Thus, colleges are required to strengthen the faculty management, formulate reasonable incentive systems to stimulate teachers' enthusiasm, and enhance teachers' comprehensive quality so that they can conscientiously stick to their posts. However, at the present phase, many colleges lack a reasonable application and incentive system. For instance, colleges don' t have enough humanistic care, pay too much attention to the incentive function of material benefits, have unclear incentive structures and low incentive effects etc. An imperfect and unreasonable incentive system will affect the teachers' teaching conditions and they gradually become sluggish. Besides, some teachers even bring their passive and negative emotions in classroom teaching. This not only severely influences the implementing effect of preschool education major courses in colleges but also directly results in students' dissatisfaction with the course implementation.

\section{3) Analysis on the specialized curriculum setting of preschool education}

Firstly, some undergraduate students and early childhood education workers think that knowledge courses are divorced from the teaching practice and the course contents are repeated. Since knowledge courses are the foundation of preschool education major in colleges, the failure to lay a foundation will affect the implementation of other courses.

Secondly, skill courses are the knowledge which must be mastered by college students. However, the limited class hours of skill courses in college teaching at the present phase fail to meet students' need for such courses and thus they are dissatisfied.

Finally, practice courses are mainly college students' probations. However, due to the disperse probation mode and short time of probation, students cannot sufficiently understand kindergarten activities; meanwhile, the probation evaluation is not satisfactory because students lack the professional teachers' guidance. Many students reflected the unsatisfactory effect of such a probation mode. Therefore, the case university carried out concentrated probation. Students were arranged for concentrated probation for a week every semester and wrote down their probation observation records. This mode was welcomed by both teachers and students. However, there are still some problems to be solved in concentrated probation. For this reason, college probation advisors 
need to give full play to their functions, timely organize some student probation exchange meetings etc. and timely solve the problems caught in students' probations effectively. In spite of this, there are still some problems in students' probation such as college' s lack of communication and contact with students' internship units, internship advisors' few contacts with students and the single internship content etc.

\section{Problems and perfecting suggestions of professional curriculum setting in China's preschool education}

This paper concluded the problems in the specialized curriculum setting of preschool education in China's colleges through the analysis on the case university and also offered perfecting suggestions. Such problems are as follows: nonsystematic knowledge courses and insufficient association between theories and practice; improper skill course teaching mode, insufficient training time and lack of practicability; nonsystematic practice courses, single teaching mode and insufficient teachers' guidance. Meanwhile, there are also some issues in college curriculum setting and implementation mainly because of the old-fashioned college curriculum concepts, low utilization of various teaching resources, inadequate resources, and imperfect incentive systems in colleges. Besides, there are also some unreasonable points in the curriculum setting structure of preschool education major in the case university. Such unreasonable points are not only be shown in no attention paid to students' mentality and disciplinary logical capability but also be shown in the negligence of practical effect of curriculum setting in college's specialized education. Therefore, a series of reforms in specialized curriculum setting of preschool education in China's colleges are required to solve the above problems.

\section{Colleges should lay a solid foundation of knowledge courses.}

As knowledge courses are the bases for students to learn other courses, colleges need to clarify the significance of knowledge courses, enrich the contents of knowledge courses for preschool education major, expand the scope of courses and help students to enrich their own knowledge reserve. Meanwhile, colleges need to pay high attention to changes in relevant laws and regulations, timely and effectively guide students to understand relevant spirits and comprehensively know the latest news about the development of preschool education ${ }^{[3]}$. Besides, knowledge courses are a system, where all course contents correlate with each other, so colleges should attach importance to such relations; teachers should clarify their respective course tasks, figure out the emphases of their courses, avoid curriculum repetition, lower resource waste, arouse students' interest, and enhance students' knowledge learning efficiency and quality. Since knowledge courses are part of college preschool education, it is required to give full play to the foundation role when selecting the course contents so as to provide theoretical supports for skill and practice courses.

\section{Colleges should pay more attention to skill courses.}

Students generally thought there were few class hours of skill courses; kindergarten teachers expressed the significance of skill learning in the future work; some kindergarten heads said that students lacked specialized skills and techniques. Thus, colleges should pay high attention to this problem and make proper adjustments to ensure that students can have effective class hours of skill courses. Besides, colleges can reasonably select the class hours of required and elective courses based on their own needs so that they can painstakingly make up for the shortcomings in skill course setting, meet students' need and thus help students' self-development. In the meantime, colleges need to set some strongly practical courses such as art course based on children' s features, focus on the kindergarten teachers' communication skills with children and some organization ways of activities. Furthermore, in order to help students to master a professional skill, colleges can set characteristic classrooms based on their actual conditions to cultivate students' abilities so that students can stand out from their future employment. 


\section{Colleges should intensify the practice course teaching.}

Colleges need to guarantee that students have enough internship time so that students can comprehensively know the work in a kindergarten, obtain more chances to train their abilities and have the ability to independently solve working problems after internship. Furthermore, colleges can also put the internship teaching throughout the four-year teaching in colleges. New students should make practices after systematically learning and understanding theoretical knowledge; then, internship activities can be carried out year by year so as to intensify students' internship effect, truly train students and help them to achieve true harvests. To attain the goal of training students and cultivating high-quality professionals, colleges can establish a practice base with diversified contents. Students' internship activities should not be limited to cities but should be expanded to rural areas and some remote regions; in this way, students' adaptability can be largely enhanced and more training opportunities can be provided to them. Meanwhile, colleges need to strengthen the contacts between students and their internship advisors so that their internship advisors can timely solve any of their difficulties; besides, they also need to encourage students to record their internship or practice activities and make comprehensive evaluations on their practice conditions.

\section{Conclusion}

In conclusion, there are still some problems in the specialized curriculum setting of preschool education in colleges. For this reason, colleges should timely make adjustments and reforms to help students to improve their abilities and lay a solid foundation for their future work. Meanwhile, students also need to timely conclude their shortcomings, make efforts together with their colleges, enhance their comprehensive quality, train their social adaptability, cultivate their problem-solving ability in work, better help their own development and help development of colleges.

\section{References}

[1] He Tengteng and Tang Wenxiu. Brief analysis on problems and countermeasures of preschool psychology curriculum setting in colleges, Science \& Technology View, 2014 (36): 31-32.

[2] Yang Xiaoqian. Brief discussion on the study on specialized curriculum setting of college preschool education, College Education, 2013 (14): 30-31.

[3] Zhang Yongxia. Problems and suggestions of specialized curriculum setting of preschool education in vocational colleges, Journal of Qiqihar Teachers College, 2012(6):24-25. 